Journal

of the

Australian earls medieval

association

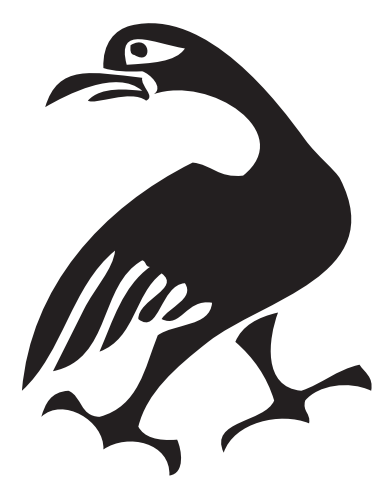

volume 9

2013 
Published in Australia by

\section{The Australian Early Medieval Association Inc.}

Incorporated Association No A0045152M

The Australian Early Medieval Association encourages and supports the study of the early medieval period by facilitating the exchange of ideas and information amongst members. Journal of the Australian Early Medieval Association is distributed free to members of AEMA. This peer-reviewed journal of scholarly articles and book reviews, established in 2005, showcases both Australian and international research on all aspects of the early medieval period from Late Antiquity and the end of the Roman empire to the end of the eleventh century.

\section{Notes for Contributors}

The journal welcomes papers on historical, literary, archaeological, cultural, and artistic themes, particularly interdisciplinary papers and those that make an innovative and significant contribution to the understanding of the early medieval world and stimulate further discussion. For submission details, please see "Publications" on the association website: www.aema.net.au. Submissions then may be sent to journal@aema.net.au.

\section{ISSN: $1449-9320$}

The material in this journal is copyright. Apart from any fair dealing for the purpose of private study, research, criticism, or review, as permitted under the Copyright Act, no part may be reproduced by any process without written permission from the authors and publisher. 


\section{contents}

Editorial Advisory Board

Committee of the Australian Early Medieval Association 2013

\section{Articles}

Nigel WeStBROOK

Notes towards the Reconstruction of the Forum of the Strategion and its Related Roads in Early Byzantine Constantinople

STEPHEN JOYCE

Gildas and his Prophecy for Britain

SHANE H. MCLEOD

The Acculturation of Scandinavians in England:

A Consideration of the Burial Record

CHRIS BISHOP

Stretching the Truth? 'The 'Rack' in Anglo-Saxon England

\section{Book Reviews}

Darby, Peter, Bede and the End of Time

(reviewed by Denise M. Doyle)

Ferreiro, Alberto, The Visigoths in Gaul and Iberia (Update):

A Supplemental Bibliography, 2007-2009

(reviewed by Geoffrey D. Dunn)

Foot, Sarah, Ethelstan: The First King of England

(reviewed by Shane McLeod)

Hamerow, Helena, David A. Hinton and Sally Crawford (eds),

The Oxford Handbook of Anglo-Saxon Archaeology

(reviewed by Roderick W. McDonald)

Kershaw, Jane E., Viking Identities: Scandinavian Jewellery

in England

(reviewed by John Kennedy) 
Lambert, Malcolm, Christians and Pagans: The Conversion of Britain from Alban to Bede

(reviewed by Stephen Joyce)

Licence, Tom, Hermits and Recluses in English Society 950-1200

(reviewed by Denise M. Doyle)

McCormick, Michael, Charlemagne's Survey of the Holy Land

(reviewed by Denise Doyle)

Maximus the Confessor(translated by Stephen Shoemaker),

The Life of the Virgin

(reviewed by John D'Alton)

Miller, Sarah Alison, Medieval Monstrosity and the Female Body

(reviewed by Chris Bishop)

O'Donoghue, Neil Xavier, The Eucharist in Pre-Norman Ireland

(reviewed by Denise Doyle)

Peters, Greg, Peter of Damascus: Byzantine Monk and Spiritual Theologian (reviewed by John D'Alton)

Raffensperger, Christian, Reimagining Europe: Kievan Rus'

in the Medieval World

(reviewed by Shane McLeod)

Ranković, Slavica, et al. (eds), Modes of Authorship in the

Middle Ages

(reviewed by Hannah Burrows)

Roffe, David, Decoding Domesday

(reviewed by Tessa Morrison)

Rosenthal, Joel T. (ed.), Understanding Medieval Primary Sources:

Using Historical Sources to Discover Medieval Europe

(reviewed by Kathryn Smithies)

Royer-Hemet, Catherine (ed.), Canterbury: A Medieval City

(reviewed by Tessa Morrison)

Rudolph, Conrad (ed.), A Companion to Medieval Art:

Romanesque and Gothic in Northern Europe

(reviewed by Kathryn Smithies) 
Saak, E.L., Creating Augustine: Interpreting Augustine and Augustinianism in the Later Middle Ages

(reviewed by John D'Alton)

Sarris, Peter, Empires of Faith: The Fall of Rome to the

Rise of Islam, 500-700

(reviewed by Geoffrey D. Dunn)

Staley, Lynn, The Island Garden: England's Language

of Nation from Gildas to Marvell

(reviewed by Roderick W. McDonald)

Winroth, Anders, The Conversion of Scandinavia:

Vikings, Merchants and Missionaries in the Remaking of Northern Europe (reviewed by Roderick W. McDonald)

Winstead, Karen A., The Life of Saint Katherine of Alexandria

by John Capgrave

(reviewed by John Scahill) 


\section{edicorial advisory board}

Editor:

Geoffrey D. Dunn

Reviews Editor:

Darius von Güttner Sporzyński

Production Editor:

Katrina Burge

Members:

Andrew Gillett, Macquarie University

James Graham-Campbell, emeritus, University College London

Rosemary Huisman, University of Sydney

Joanna Huntington, University of Lincoln

John Melville-Jones, University of Western Australia

John Moorhead, emeritus, University of Queensland

\section{commircee of the auscralian early medieval associacion 2013}

John D'Alton

Geoffrey D. Dunn

Darius von Güttner Sporzyński

Roderick McDonald

Shane H. McLeod

Timothy Scott

Hollie Thomas

Janet Wade

(Katrina Burge) 



\title{
the acculcuracion of scandinavians in england: a consideration of the burial Record
}

\author{
Shane H. McLeod \\ University of Tasmania
}

\begin{abstract}
The portrayal of the 'Vikings' as an archetypal barbarian 'other,' wreaking death and destruction wherever they went, was already current in the medieval period, but in England the depictions became more extreme in the centuries after the attacks. This paper will focus on the texts and archaeology of ninth- and tenthcentury England and argue that in many respects Scandinavians were not as 'other' as later medieval writers believed. Furthermore, once Scandinavian groups settled in England the notion of 'otherness' appears to have quickly disappeared. Particular attention will be paid to the burial record as a means of identifying probable Scandinavians, and for evidence of acculturation to AngloSaxon Christian burial customs. ${ }^{1}$
\end{abstract}

Of all of the European 'barbarian' groups, it is perhaps the Vikings who have the largest place in public consciousness. ${ }^{2}$ Indeed, this popular response is one of the reasons that the term 'Viking' is problematic and 'Scandinavian' is preferred in this paper. ${ }^{3}$ Although the portrayal of Scandinavian invaders and settlers has changed over the centuries, medieval sources did present Scandinavian groups as different to those who were being raided; in particular, emphasis was often placed on their non-Christian status. Yet as R.I. Page's analysis of the English material made clear, the vitriolic language, including "that filthy race," "pagans," and "barbarians," was usually written by medieval historians commenting on much earlier events and their accounts are often at odds with the reports found in the main historical source, Anglo-Saxon Chronicle (hereafter $A S C) .{ }^{4}$ For example, the gory details of the martyrdom of

${ }^{1}$ I would like to thank the reader for the most helpful comments. All errors remain my own.

2 Recent examples of the continuing popularity of Vikings amongst the general public are the 2011 film Thor and the series of Viking novels by Tim Severin.

3 Putting aside modern images of hairy warriors in horned helmets, technically a Viking was someone who raided, so it does not encompass non-combatants such as peaceful settles, crafts-people, traders, women and children. 'Scandinavian' is used to denote someone who was likely to have had an ancestral home in Scandinavia, regardless of where they currently resided or were born, and displayed some Scandinavian cultural traits, such as jewellery with Scandinavian art motifs and speaking the Old Norse language.

${ }^{4}$ R.I. Page, 'A Most Vile People': Early English Historians on the Vikings (London: Viking Society for Northern Research, 1987). An exception is Asser's Life of King Alfred written in 893, but

JAEMA 9 (2013) 69-97 (C) the author and Australian Early Medieval Association 
journal of the auscralian early medieval associacion

St Edmund and reports of the wanton destruction of churches by the Scandinavians both emanate from texts written a century or more after the (possible) events described. ${ }^{5}$ Instead, the primary sources suggest that, although points of difference are evident, in many respects the Scandinavians who raided and settled England in the ninth and tenth centuries had many similarities to the Anglo-Saxons whom they fought. Following a brief review of the origins of both groups and an analysis of the contemporary written record, this paper will concentrate on the evidence from Scandinavian burials as, due to conscious choices being involved, different Scandinavian burial practices found in England provide a valuable guide to cultural differences and efforts at acculturation. A comparison of the burial record with the ornamental metalwork evidence will also be made to extend the discussion of 'acculturation.' The paper will focus on the main period of Scandinavian settlement, from c. 865-950. Due to the process of acculturation it is difficult to distinguish between Scandinavian and Anglo-Saxon burials after 950, and indeed often before that date, and this aspect of difference effectively disappears.

Considering their similar geographic origins, cultural similarities between Scandinavians and Anglo-Saxons should come as little surprise. Of the three Anglo-Saxon groups who invaded Britain named by Bede, two, the Angles and Jutes, came from what would become Viking Age Denmark, whilst other evidence suggests participation in the migration from groups elsewhere in Scandinavia. ${ }^{6}$ Consequently, Scandinavians and

his description of the Scandinavians is not as extreme as later works by Æthelweard and Henry of Huntingdon. See Page for commentary.

5 The earliest account of Edmund being shot full of arrows and beheaded in 870/871 occurs in Abbo of Fleury's Passion of St Edmund written in 985-987. For a translation, see Abbo of Fleury, "Passio Sancti Eadmundi/The Passion of Saint Eadmund," in F. Hervey (ed. and trans.), Corolla Sancti Eadmundi: The Garland of Saint Edmund King and Martyr (London: J. Murray, 1907), 18-35. A good example of later 'additional' material regarding attacks on churches is found in the mid-twelfth century work Liber Eliensis 1.40 (J. Fairweather [trans.], Liber Eliensis: A History of the Isle of Ely from the Seventh Century to the Twelfth [Woodbridge: Boydell Press, 2005], 73-74).

${ }^{6}$ Bede, Historia ecclesiastica gentis Anglorum 1.15 (L. Sherley-Price [trans.], Bede: A History of the English Church and People [Harmondsworth: Penguin, 1978], 56). For the likely participation of people from Scandinavia beyond Jutland in particular, see J. Hines, The Scandinavian Character of Anglian England in the pre-Viking Period, British Archeological Reports British Series, vol. 124 (Oxford: British Archaeological Reports, 1984) especially 270-285; and J. Hines, "The Scandinavian Character of Anglian England: An Update," in M. Carver (ed.), The Age of Sutton Hoo: Seventh Century in North-western Europe (Woodbridge: Boydell Press, 1992), 315-329. 
Anglo-Saxons shared legendary heroes and ancestors, and Old Norse and Old English are likely to have been mutually intelligible to a degree during the Viking Age. ${ }^{7}$ Similarly, most of the events in the Anglo-Saxon poem Beowulf take place in Scandinavia and both Scandinavians and AngloSaxons would have recognised the heroic culture that the poem depicts. Consequently, in many respects Scandinavians were more akin to distant cousins to the Anglo-Saxons than an alien 'other.' Indeed, someone working with migration theory would consider Viking Age Scandinavian settlement in England as an expected continuation of migration along the routes from Scandinavia established centuries earlier. ${ }^{8}$

The most significant cultural difference between Anglo-Saxons and Scandinavians in the mid-ninth to mid-tenth centuries is that the AngloSaxon kingdoms had converted to Christianity, at least officially, by the late seventh century, whereas when the first Scandinavian settlements occurred in England from 876, the immigrants appear to have been pagan. ${ }^{9}$ Indeed, the successful conversion of Scandinavia is generally dated from c. 965 and the conversion of the Danish king Harald Bluetooth. ${ }^{10}$ It is this difference which is highlighted by Asser, a Welsh monk at the court of Wessex, in his biography of King Alfred, in which

7 For example Anglo-Saxon Woden is Scandinavian Óðinn, Thunor is Dórr, etc. For the likelihood of mutual intelligibility, see M. Townend, Language and History in Viking Age England. Linguistic Relations between Speakers of Old Norse and Old English, Studies in the Early Middle Ages, vol. 6 (Turnhout: Brepols, 2002).

8 For a discussion of migration theory and its applicability to medieval migrations, see D. Anthony, "Prehistoric Migration as Social Process," in J. Chapman and H. Hamerow (eds), Migrations and Invasions in Archaeological Explanation, British Archaeological Reports International Series, vol. 664 (Oxford: British Archaeological Reports, 1997), 21-32. For its application to the Scandinavian migration to England in the ninth-century, see S.H. McLeod, The Beginning of Scandinavian Settlement in England: The Viking Great Army and Early Settlers, c. 865-900, Studies in the Early Middle Ages, vol. 29 (Turnhout: Brepols, 2013).

9 The conversion of the Anglo-Saxons is principally known from Bede's Historia ecclesiastica gentis Anglorum. The baptism of individual Norse-speaking people is reported on the continent in the eighth and ninth centuries, but neither Scandinavia nor any Viking settlements are known to have been completely converted prior to 875. See B. Sawyer, P. Sawyer, and I. Wood (eds), The Christianization of Scandinavia Report of a Symposium beld at Kungalv, Sweden 4-9 August 1985 (Alingså: Viktoria Bokforlags, 1987). The notice of the first settlement in England can be found in M.J. Swanton (ed. and trans.), The Anglo-Saxon Chronicles (London: Phoenix, 2000) annal for 876, 74. The earliest extant version, the 'A' text, will be cited unless otherwise specified.

${ }^{10}$ For a detailed investigation of the conversion of Scandinavia see A. Sanmark, Power and Conversion: A Comparative Study of Christianization in Scandinavia, Occasional Papers in Archaeology, vol. 34 (Uppsala: Uppsala University, 2004). 
he often uses the Latin pagani for the Scandinavians, including one instance in which it is used as an ethnic name for them. ${ }^{11}$ Indeed, Asser has been accused of deliberately creating a sense of religious war. ${ }^{12}$ As will be discussed below, this is in stark contrast to the text from which he was getting much of his information: $A S C .{ }^{13}$

It is curious that terms such as "heathens," "pagans," and "barbarians" were not used for the Scandinavian conquerors and settlers in the earliest version of $A S C$ (recension A), particularly since the annals of the period covered by this paper are thought to have been written soon after the events described. ${ }^{14}$ The conquests that culminated in the first recorded settlements of Scandinavians in England were instigated by a group commonly referred to as the great army (a rendering of the Old English micel here), for which ASC usually uses the terms "raiding-army" (bere) and "Danes" (Deniscan). ${ }^{15}$ The oft-quoted "great heathen raidingarmy" (mycel haden here) does not actually occur in the earliest extant version of $A S C$, but instead appears in later recensions. ${ }^{16}$ Even if the absence of 'heathen' in the annal for 866 in $A S C$ 'A' is discounted, it is somewhat startling that the term rarely appears elsewhere in any of the recensions of $A S C$ for the activities of the Scandinavians. The annal for

11 For Asser's use of pagani see R.I. Page, "The Audience of Beowulf and the Vikings," in C. Chase (ed.), The Dating of Beomulf (Toronto: University of Toronto Press, 1997), 113-122, at 119. For the text see Asser, Life of King Alfred in S. Keynes and M. Lapidge (eds and trans.), Alfred the Great. Asser's Life of King Alfred and Other Contemporary Sources (London: Penguin Books, 1983).

12 Keynes and Lapidge, Alfred the Great, 230-231, n. 12.

13 Asser largely borrows from ASC down to the annal for 887. See Keynes and Lapidge, Alfred the Great, 55-56. For the bias of the written sources, see P.H. Sawyer, The Age of the Vikings, 2nd edn (London: Palgrave Macmillan, 1971), 31-32.

${ }^{14}$ ASC is thought to have been in existence by $890 / 892$ according to B.E. Yorke, "The Representation of Early West Saxon History in the Anglo-Saxon Chronicle," in A. Jorgensen (ed.), Reading the Anglo-Saxon Chronicle: Language, Literature, History, Studies in the Early Middle Ages, vol. 23(Turnhout: Brepols, 2010), 141-159, at 158.

15 For the original text, see J. Bately (ed.), The Anglo-Saxon Chronicle: A Collaborative Edition, vol. 3: $M S A$ (Cambridge: D.S. Brewer, 1986). An example of here can be found in the annal for 869 and Deniscan in 870 on 47.

16 The term has recently been used as the chapter title, "The 'Great Heathen Army' in England," in R. Hall, Exploring the World of the Vikings (London: Thames and Hudson, 2007), 82-85, at 82. For the text without 'heathen' see ASC 866 (Bately, The Anglo-Saxon Chronicle, 47). 'Heathen' appears in texts B, C, D, and E. For the texts side by side see B. Thorpe (ed. and trans.), The Anglo-Saxon Chronicle According to the Several Original Authorities, vol. 1: Original Texts (Wiesbaden: Kraus Reprint, 1964), 130-131. For the dating of the different manuscripts, see Swanton, The Anglo-Saxon Chronicles, xxi--xxviii. 
871 describes two of the Scandinavian leaders as "heathen kings" (bepnan cyningas), which would suggest that some members of the army would also be pagans. But the term "heathen" does not appear again until the poem known as The Capture of the Five Boroughs which makes up much of the annal for 942 in recensions A, B, C, and D. ${ }^{17}$ So for seventy years, a period that saw almost yearly battles between Anglo-Saxons and various Scandinavian groups and witnessed Scandinavian control and settlement of much of eastern and northern England, ASC fails to highlight the religion of the Scandinavians. The closest $A S C$ otherwise comes to highlighting religious differences are two entries, for 893 and 896, when the Anglo-Saxon forces are described as "Christians," which may suggest that the Scandinavians whom they had just defeated were not Christian. ${ }^{18}$ Similarly, that some Scandinavians were baptised in England may suggest that they had not been Christian previously. ${ }^{19}$ The evidence of $A S C$ does not mean that most of the Scandinavians were not "heathens," but it clearly demonstrates that any religious difference was of little interest to the chroniclers.

Indeed, the Scandinavians conquering and settling England were not portrayed as being particularly barbaric or 'other' in ASC. The only unusual practices recorded are the swearing of oaths on a sacred ring in 876 and perhaps the use of a raven banner in $878 .{ }^{20}$ The main difference highlighted in ASC about the Scandinavians is not about religious practices, attacks on the church or churchmen, or the ritual killing of captured Anglo-Saxon kings, all of which were attributed to Scandinavians in England during this period by later medieval, and indeed some modern, historians. Instead, the point of difference mentioned in $A S C$ is one of trust, with the Scandinavians being accused of not

17 ASC 871 (Bately, The Anglo-Saxon Chronicle, 48) and 942 (Bately, The Anglo-Saxon Chronicle, 73).

18 Ibid., 893 (Bately, The Anglo-Saxon Chronicle, 58 and 61).

19 For example, Guthrum and twenty-nine other members of the great army were baptised after being defeated by Alfred of Wessex in 878; and Alfred and Æthelred of Mercia were godfathers of two sons of the Viking leader Hæsten, ASC 878 (Swanton, The Anglo-Saxon Chronicles, 76) and 893 (Swanton, The Anglo-Saxon Chronicles, 86).

${ }^{20}$ Ibid., 876 (Swanton, The Anglo-Saxon Chronicles, 74) and 878 (Swanton, The Anglo-Saxon Chronicles, 77) from ' $E$ ' recension. The raven banner is not mentioned in the 'A' manuscript but in the later ' $E$ ' recension. For the uses of raven symbolism by Scandinavians (primarily based on later sources), see L. Wild, "The Raven Banner at Clontarf: The Context of an Old Norse Legendary Symbol,” in K.L. Burge (ed.), Vikings and their Enemies (Melbourne: Viking Research Network, 2008), 37-48. 
journal of the auscralian early medieval associacion

honouring the terms of peace agreements. ${ }^{21}$ Indeed, when agreements were adhered to special comment is made as though it was unexpected.22 However, from a modern perspective the alleged untrustworthiness of Scandinavians is not always clear. Apart from the possible language difficulties of recent Scandinavian immigrants understanding the specifics of an agreement with Anglo-Saxons, and how well they recognised the boundaries of different Anglo-Saxon kingdoms, it is impossible to know, for example, how important the great army leader Guthrum considered his oaths sworn to Alfred on the sacred ring in 876 to be. ${ }^{23}$ More dubious still are the records of the descendants of Scandinavians, by now long settled and in political control of the kingdoms of East Anglia and southern Northumbria (then centred on York), breaking the peace against King Edward of Wessex. When Edward spent five weeks inside enemy territory in 909, raiding it and killing many men and destroying much property, there is no mention of him breaking the peace. ${ }^{24}$ This is despite a peace agreement being confirmed between Edward and the East Anglians and Northumbrians in 905, and no mention of hostilities prior to Edward's raid. ${ }^{25}$ Yet when the Northumbrians raided Edward's territory the following year, presumably in retaliation (they apparently scorned a new peace deal offered by Edward), they are accused of breaking the peace. ${ }^{26}$ There can be little doubt that the accounts of the untrustworthiness of Scandinavians in $A S C$ are biased.

That the failure to honour agreements is the one point of difference from the Anglo-Saxons consistently mentioned in $A S C$ suggests that in other regards, such as their appearance and their way of waging war, the Scandinavians were either considered to not be so different, or that the difference was not worth mentioning. Indeed, the first Scandinavian king of East Anglia, Guthrum, has his death recorded in ASC as though he was an accepted king of an Anglo-Saxon kingdom. The chronicle even recorded both his Scandinavian name and his Anglo-Saxon baptismal

21 See, for example, ASC 876 (Swanton, The Anglo-Saxon Chronicles, 74); 885 (Swanton, The Anglo-Saxon Chronicles, 80); 894 (Swanton, The Anglo-Saxon Chronicles, 84); 911 (Swanton, The Anglo-Saxon Chronicles, 86-87); 917 (Swanton, The Anglo-Saxon Chronicles, 96); 918 (Swanton, The Anglo-Saxon Chronicles, 98); and 921 (Swanton, The Anglo-Saxon Chronicles, 101).

22 For example, on the great army's last dealings with Alfred, see ibid. 877 (Swanton, The Anglo-Saxon Chronicles, 74) and 878 (Swanton, The Anglo-Saxon Chronicles, 76).

${ }^{23}$ Ibid., 876 (Swanton, The Anglo-Saxon Chronicles, 74).

24 Ibid., 910 (Swanton, The Anglo-Saxon Chronicles, 94 and 96).

25 Ibid., 906 (Swanton, The Anglo-Saxon Chronicles, 94).

26 Ibid., 911 (Swanton, The Anglo-Saxon Chronicles, 96). 
name, Æthelstan, and makes no negative comments. ${ }^{27}$ It has been noted that only the deaths of Scandinavian leaders killed by Anglo-Saxons are recorded in $A S C$, so the recording of Guthrum's death is an exception which demonstrates that this former enemy had become an accepted part of the Anglo-Saxon political landscape. ${ }^{28}$

In terms of possible differences, the failure of largely contemporary annals to mention attacks on churches is surprising as one would consider it to be of interest to both the chroniclers and their audience. The destructive impact of the great army on St Wystan's at Repton, Derbyshire, then in the centre of the kingdom of Mercia, which was incorporated into their winter fort of 873-874, is obvious from recent excavations. ${ }^{29}$ This provides some credibility to other accounts of Scandinavian attacks on churches, for example the twelfth-century addition to the Peterborough text ('E') of $A S C$ recording an attack on Peterborough in 870 , although the severity of the attack may be an exaggeration. ${ }^{30}$ The destruction of St Wystan's is not recorded in any text of $A S C$, perhaps suggesting that it was not known to the Wessex-based chronicler. It is also the only certain example of Scandinavians having a detrimental effect on a church building. Indeed, the failure of ASC to mention any Scandinavian attacks on churches in Wessex, despite their extensive campaigns there in the 870 s and 890 s, strongly suggests that churches were not badly damaged. If this were the case then it argues against the notion of Scandinavian armies deliberately destroying churches, and the damage done to St Wystan's appears to have been due to practical logistics rather than anti-Christian sentiment. There are other candidates for church buildings damaged by Scandinavian armies, most notable Monkwearmouth, Durham, where burning was evident, but problems with precisely dating such damage makes it impossible to attribute the destruction to Scandinavians. Additionally, there exists evidence of some continuity at many of the sites that later medieval

${ }^{27}$ Ibid., 890 (Swanton, The Anglo-Saxon Chronicles, 82).

${ }^{28}$ J. Stodnik, "Sentence to Story: Reading the Anglo-Saxon Chronicle as Formulary," in A. Jorgensen (ed.), Reading the Anglo-Saxon Chronicle: Language, Literature, History, Studies in the Early Middle Ages, vol. 23 (Turnhout: Brepols, 2010), 91-111, at 101.

29 M. Biddle and B. Kjølbye-Biddle, "Repton and the 'great heathen army' 873-4," in J. Graham-Campbell, R.A. Hall, J. Jesch, and D.N. Parsons (eds), Vikings and the Danelaw: Select Papers from the Proceedings of the Thirteenth Viking Congress (Oxford: Oxbow Books, 2001), 45-96, at 57-60.

${ }^{30}$ For the attack see $A S C 870$ (Swanton, The Anglo-Saxon Chronicles, 71), recension 'E'. 
journal of the australian early medieval association

writers claimed were destroyed by Scandinavians. ${ }^{31}$ So far those Scandinavians who settled in England do not appear to have been particularly 'other' or barbaric.

Yet when the burial evidence is considered some clear differences emerge, despite, again, the silence on the matter in the written sources. Following a brief overview of the Scandinavian burial evidence, its significance will be discussed. ${ }^{32}$

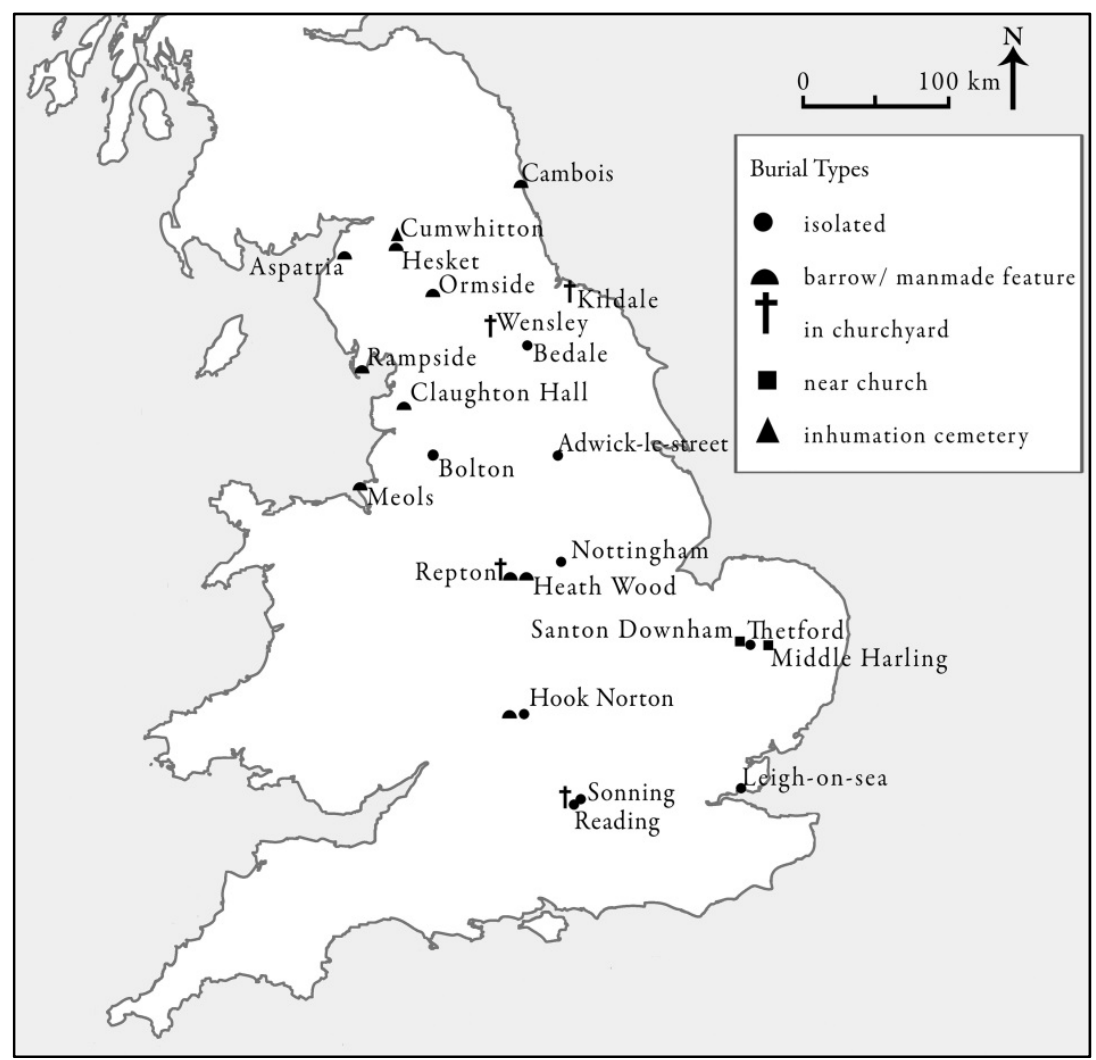

Figure 1 Scandanavian burials in England, c. 865-950

Source: Map drawn by Aurore McLeod.

${ }^{31}$ For an overview of the evidence for the destruction and survival of church buildings see D.M. Hadley, The Vikings in England: Settlement, Society and Culture (Manchester: Manchester University Press, 2006), 194-207

${ }^{32}$ For a map of the burials see fig. 1. 
Cremation is the most obviously non-Christian style of burial practiced during the medieval period, and by the mid-to-late ninth century cremation was most certainly not in the repertoire of Anglo-Saxon burial practices, with the last cremations occurring in the seventh century. ${ }^{33}$ Consequently, cremation was re-introduced to England by Scandinavians and the use of cremation would have immediately marked its practitioners out as different. However Scandinavian cremations in England are rare, comprising the large but unique barrow cemetery at Heath Wood, near Ingleby in Derbyshire, and three possible cremations found by antiquarians in the north-east, of which the most probable was found under a mound at Hesket-in-the-Forest, Cumbria. ${ }^{34}$ The rarity of Scandinavian cremations in England and elsewhere in Britain, suggests that those in England might have been made by migrants embarking directly from Scandinavia who were continuing their traditional burial practices regardless of their new location. ${ }^{35}$ The similarity between the Heath Wood and Hesket mounds, include the mounds being newly constructed, the cremation of animals, and a layer of clean sand underlying some of the cremations, may strengthen this possibility, or could suggest that people who had been involved in the Heath Wood cemetery later moved to the north-west and built a single mound in similar style. ${ }^{36}$

The Heath Wood and Hesket-in-the-Forest cremations bring us to another point of difference between Scandinavian and contemporary Anglo-Saxon burials: the use of burial mounds, or barrows. Like

33 S. Crawford, "Cemeteries, Furnished," in M. Lapidge, J. Blair, S. Keynes and D. Scragg (eds), The Blackwell Encyclopaedia of Anglo-Saxon England (Oxford: WileyBlackwell, 2001) 90-91, at 91.

${ }^{34}$ For Heath Wood see J.D. Richards, "Excavations at the Viking Barrow Cemetery at Heath Wood, Ingleby, Derbyshire," The Antiquities Journal 84 (2004), 23-116. The other possible cremations in the north-west were at Crossmoor, Inskip, and Claughton Hall, both in Lancashire, see A.Z. Redmond, Viking Burial in the North of England: A Study of Contact, Interaction and Reaction between Scandinavian Migrants with Resident Groups, and the Effect of Immigration on Aspects of Cultural Continuity, British Archaeological Reports British Series, vol. 429 (Oxford: British Archaeological Reports, 2007), 92-95.

35 There are no certain Scandinavian cremations in Ireland. There are cremations known from Scotland, but all but one are thought to be later than the Heath Wood cemetery. The exception is at King's Cross Point on Arran, which may be of a similar date, according to Richards, "Excavations at the Viking Barrow Cemetery," 97-98.

${ }^{36}$ Heath Wood is dated to the 870 s and/or 880 s whilst Hesket-in-the-Forest is thought to be early tenth century, according to Richards, "Excavations at the Viking Barrow Cemetery," 98-99 
journal of the auscralian early medieval associacion

cremation, barrows had not been constructed for burials in England for over a century, so the Scandinavians effectively re-introduced a defunct burial practice to England. Indeed, this chronology is the primary reason that Alexander suggested that the burial of three people accompanied by minimal grave-goods in a mound at Cambois, near Bedlington, Northumbria was Scandinavian rather than Anglo-Saxon as earlier scholars had supposed. ${ }^{37}$ These burials were inserted into what is described as a tumulus, a word usually used to describe an artificial mound although Angela Redmond has suggested that this mound might have been natural. ${ }^{38}$ Even if Redmond is correct, and there is no reason to suspect that the author of the nineteenth-century report was not using "tumulous" with its usual meaning, those performing the burial at Cambois would not necessarily have realised that the mound was natural and might have thought that they were adding their dead to an existing barrow.

Regardless of the uncertain status of the Cambois mound, there are other certain Scandinavian mound burials where a pre-existing barrow was used. Scandinavian remains represent secondary burials in Bronze Age barrows at Aspatria (on the summit of Beacon Hill), Cumbria, and Claughton Hall, near Garstang, Lancashire. ${ }^{39}$ Similarly, the accompanied Scandinavian churchyard burials at Rampside, Lancashire, and Ormside, Westmorland, may have been earlier than those churches and were also reusing earlier man-made features. At Rampside two Scandinavian burials were placed on top of a Neolithic long barrow, whilst at Ormside the burial is on an undated man-made earthwork. ${ }^{40}$ If these burials were earlier than the churches they may have been the reason for churchyards later appearing on these man-made landscape features. Additionally, there is a possible mound burial (no body was reported with the antiquarian find) in sand dunes at Meols, Wirral, Cheshire, where a deliberately-bent

37 M.L. Alexander, "A 'Viking Age' Grave from Cambois, Bedlington, Northumberland," Medieval Archaeology 31 (1987), 101-105. Following Alexander's reappraisal it has been included in the corpus of likely Scandinavian burials, e.g., by Hadley, The Vikings in England, 241; J.D. Richards, Viking Age England (Stroud: Tempus, 2004 [2nd edn]), 194. However Redmond, Viking Burial in the North of England, 116, is more skeptical.

38 Redmond, Viking Burial in the North of England, 116.

39 Ibid., 94; P. Abramson, "A Re-examination of a Viking Age Burial at Beacon Hill, Aspatria," Transactions of the Cumberland and Westmorland Antiquarian and Archaeological Society 100 (2000), 79-88.

${ }^{40}$ Redmond, Viking Burial in the North of England, 106-108. 
arrowhead, a spearhead, and an axe were recovered. ${ }^{41}$ Considering its location, this is likely to have been a new Scandinavian barrow and a temporary expediency. Finally, there was a probable Viking-Age barrow, "8 or 9 feet high," reported over a burial found at Hook Norton, Oxfordshire, in 1848. Another burial nearby included a hoard of coins which date the burial to $c .875 .42$

One of the most remarkable Scandinavian burials in England involved both the reuse of an existing, though no longer in use, building associated with the dead, and the raising of a new barrow. As mentioned above, the monastery of St Wystan's at Repton was converted into the winter camp of the great army in 873-874, a winter which saw the kingdom of Mercia conquered and its king flee to Rome. ${ }^{43}$ Judging by the discovery of five pennies dated to between 872 and 874 it was probably also at this time that a disused building, which is thought to have once been a mortuary chapel, was cut down to ground level, had the disarticulated remains of at least 264 people arranged within it, and then covered with a stone and pebble mound, creating a mass chamber burial. ${ }^{44}$ At one corner of the mound a grave was dug in which four young people (aged 8 to 17) were buried. They have been interpreted as sacrificial victims, killed to commemorate the closing of the mound. ${ }^{45}$

A more common type of Scandinavian burial than those discussed above appears to have been isolated inhumations without a barrow. Some of these burials may have occurred whilst Scandinavian armies were on campaign, and where logistical considerations may have demanded a quick burial, although it should be remembered that the mass burial at

41 D. Griffiths, "The Archaeological Background," in J. Graham-Campbell and R. Philpott (eds), The Huxley Viking Hoard: Scandinavian Settlement in the North West (Liverpool: National Museums Liverpool, 2009), 13-21 at 15.

42 M. Biddle and J. Blair," "The Hook Norton Hoard of 1848: A Viking Burial from Oxfordshire?" Oxoniensia 52 (1987), 186-195, at 194 for the quote (taken from an 1848 letter about the discovery of the burials).

43 ASC 874 (Swanton, The Anglo-Saxon Chronicles, 72).

44 Biddle and Kjølbye-Biddle, "Repton and the 'great heathen army' 873-4," 67-74. Although the alterations made to the building sound similar to the description of the great army "demolishing them [monasteries] from the very foundations" found in the twelfth century LiberEliensis, it is likely to just be part of the many unsubstantiated claims made in the work against the Scandinavians, rather than representing knowledge of the events at Repton. Liber Eliensis 1.39 (Fairweather, Liber Eliensis, 71).

45 Biddle and Kjølbye-Biddle, "Repton and the 'great heathen army' 873-4," 73-74. The grave is described as a "pit" in the article but the accompanying drawing suggests a grave. 
journal of the auscralian early medieval associacion

Repton was also constructed by an army on campaign, albeit at a winter camp. The weapon burials at Reading, Berkshire, which also included a horse, and Sonning, Wokingham, on opposite sides of the River Thames are both thought to be male warrior burials from the winter of 870-871, when the great army spent the winter at Reading. ${ }^{46}$ Similarly, it has been suggested that another two weapon burials found at Thetford, Norfolk, might relate to the great army's winter camp at that location in 869-870, and the Hook Norton burial with coins mentioned above may also relate to the movement of the great army. ${ }^{47}$ However isolated weapon burials without mounds appear to have continued after Scandinavians began to settle in England. In areas they settled from 876 two weapon burials possibly from the tenth century were discovered at Nottingham, a single burial with a horse, sword and coins deposited in c. 895 at Leigh-on-Sea, Essex, and one either on or beside a Roman road at Camp Hill near Bedale, North Yorkshire, which included both a spearhead and a pair of oval brooches, a common female brooch-type in Scandinavia.48 At Adwick-le-Street, South Yorkshire, a late ninth-century female burial including a pair of oval brooches and bronze bowl was found in a ditch alongside a Roman road, although the shallowness of the burial makes it possible that it was once accompanied by other burials. ${ }^{49}$ There are also probable isolated burials in the north-west of England, where the absence of locally produced primary sources make the dating of Scandinavian settlement difficult to establish. These include the probable burial from near Bolton, Lancashire. ${ }^{50}$

46 J. Graham-Campbell, "Pagan Scandinavian Burial in the Central and Southern Danelaw," in J. Graham-Campbell, R.A. Hall, J. Jesch, and D.N. Parsons (eds), Vikings and the Danelaw. Select Papers from the Proceedings of the Thirteenth Viking Congress (Oxford: Oxbow Books, 2001), 105-124, at 115.

47 J. Graham-Campbell, "The Archaeology of the 'Great Army' (865-79)," in E. Roesdahl and J.P. Schjødt (eds), Treogtyvende tvarfaglige Vikingesymposium (Aarhus: Aarhus Universitet, 2004), 30-46, at 38-39; Biddle and Blair, "The Hook Norton Hoard of 1848," 194.

48 For Nottingham see Graham-Campbell, "Pagan Scandinavian Burial," 105-106. For Bedale see Redmond, Viking Burial, 95. For Leigh-on-Sea see Hadley, The Vikings in England, 243-244. For the Scandinavian settlement of the kingdoms of Northumbria and East Anglia and the eastern part of Mercia see ASC 876-877 (Swanton, The Anglo-Saxon Chronicles, 74) and 880 (Swanton, The Anglo-Saxon Chronicles, 76).

49 G. Speed and P. Walton Rogers, "A Burial of a Viking Woman at Adwick-le-Street, South Yorkshire,” Medieval Archaeology 48 (2004), 51-90, at 88-89.

50 B. Edwards and J. Graham-Campbell, "An Eighteenth-Century Record of a Lancashire Viking Burial," Transactions of the Lancashire and Cheshire Antiquarian Society 
There are two other accompanied inhumations without mounds which are a little more difficult to describe as 'isolated'. Both are thought to belong to the post-settlement period and were in the Scandinavianruled kingdom of East Anglia. At Santon Downham, Norfolk, there was a burial with a sword and pair of oval brooches, whilst at Middle Harling, Norfolk, a burial with four small knives and a whetstone has been interpreted as that of a craftsman. ${ }^{51}$ However their locations, on the slope of a hill north of a church and in a ditch that was possibly a churchyard boundary respectively, imply that both may have had some association with Christian cemeteries.

This brings us to another category of Scandinavian burials in England: accompanied churchyard inhumations with Christian alignment, known as transitional burials. These were still different from the contemporary Anglo-Saxon norm, in which churchyard burials often included items associated with costume, including small knives, but no longer featured more elaborate grave-goods such as swords and bowls. ${ }^{52}$ For this reason possible transitional burials that included small VikingAge costume-related objects, such as a tenth-century bone comb at St Patrick's Chapel, Heysham, Lancashire, and tenth-century buckles, strap-ends, knives, and a comb case at Carlisle, Cumbria, will not feature in this discussion. ${ }^{53}$ Some of the accompanied Scandinavian churchyard burials belong to the period of conquest when the great army was on the campaign that saw them win lands to settle. The earliest of these burials would appear to be in St Mary's churchyard, Reading, where a coffin burial contained at least eleven coins. As it is thought that the coins were deposited in c. 870-871 and Reading is not an area in which Scandinavians settled, this burial, like the isolated weapon burials as at Reading and Sonning discussed above, is likely to date to the 870-871 winter camp of the great army. ${ }^{54}$ Another three accompanied churchyard burials recovered from St Wystan's, Repton, all of which have been subjected to stable isotope analysis to determine where the individuals had spent their childhood's, are also thought to date to the campaigning period, probably

104 (2008), 151-158. See 158 of this article and Griffiths, "The Archaeological Background," 15, for other possible Scandinavian burials.

51 Graham-Campbell, "Pagan Scandinavian Burial," 110-112.

${ }^{52}$ For a review of contemporary Anglo-Saxon burial practices see Hadley, The Vikings in England, 246-249.

${ }^{53}$ See Griffiths, "The Archaeological Background," 16 for these examples.

54 Graham-Campbell, 'Pagan Scandinavian Burial,' 115. 
journal of the auscralian early medieval associacion

the winter camp of 873-874.55 Unlike the St Mary's burial, one of the churchyard burials at Repton contained extensive grave goods, including a sword, a hammer pendant popularly associated with the Scandinavian god Dórr, and possible symbolic objects in a jackdaw humerus and a boar's tusk. This burial was also covered with a low mound of stones about 40 centimetres high. ${ }^{56}$ However the other two certain Scandinavian burials at Repton contained minimal grave goods, including a knife with one and five coins dated to the mid-870s with the other. ${ }^{57}$ Later accompanied churchyard burials include one with a sword, spear, knife, and sickle at Wensley, Yorkshire, and eight or nine inhumations accompanied by four swords, knives, an axe, and a set of scales actually found under the nave of the church at Kildale, Yorkshire. ${ }^{58}$ As with the churchyard burials at Rampside and Ormside discussed above, the burials at Kildale may be earlier than the church. A number of Viking-Age weapon finds from English churchyards may also represent disturbed burials. ${ }^{59}$

A final type of Scandinavian burial site in England is that of an inhumation cemetery not associated with a church. The only example known in England is the cemetery at Cumwhitton, Cumbria, discovered by metal-detectorists in 2004, but a number are known in Scotland. ${ }^{60}$ The Cumwhitton hilltop cemetery consisted of six burials whose grave-goods included oval brooches, swords, knives, spearheads, an axe, a shield, and an arm-ring. ${ }^{61}$ The burials do not appear to have been covered by mounds, although one was marked by a ditch which may suggest a

${ }^{55}$ For the isotope results see P. Budd, A. Millard, C. Chenery, S. Lucy, and C. Roberts, "Investigating Population Movement by Stable Isotope Analysis: A Report from Britain," Antiquity 78:299 (2004), 127-141, at 137-138.

56 Biddle and Kjølbye-Biddle, "Repton and the 'great heathen army' 873-4," 60-65. The stone mound was also associated with one of the two burials discussed below, which was placed beside the one currently under discussion.

${ }^{57}$ Ibid., 65. The certain burials are those where stable isotope analysis has showed that those buried had spent their childhoods living in places known to have had a Scandinavian population in the ninth century.

58 Redmond, Viking Burial in the North of England, 110.

${ }^{59}$ For example an axe at Repton (Biddle and Kjølbye-Biddle, "Repton and the 'great eathen army' 873-4," 65) and a spearhead beneath a Scandinavian hogback sculpture at Heysham, Lancashire (Redmond, Viking Burial in the North of England, 108).

${ }^{60}$ M. Brennand, "Finding the Viking Dead," Current Archaeology 204 (2006), 623-629. For an updated report see R. Newman, "The Cumwhitton Viking Cemetery," in J. Graham-Campbell and R. Philpott (eds), The Huxley Viking Hoard: Scandinavian Settlement in the North West (Liverpool: National Museums Liverpool, 2009), 21-23. For cemeteries in Scotland, see Redmond, Viking Burial in the North of England, 74-84.

${ }^{61}$ Brennand, "Finding the Viking Dead," 623, 626-627. 
mound. ${ }^{62}$ Despite the absence of a church and the inclusion of gravegoods, the deceased appear to have been laid on their backs and the graves were aligned roughly east-west. It has been suggested that the graves were orientated so that the dead overlooked the present village of Cumwhitton, where the Scandinavian community may have lived. ${ }^{63}$

The first thing to be noted about the record of Scandinavian burial in England is the sheer number of options that were available to those who were deciding how to bury their dead: cremation or inhumation?; new barrow, existing barrow, or no barrow?; extensive or minimal gravegoods?; exactly which items should be included with the burial?; whereabouts in the landscape should the burial take place?; churchyard, new cemetery, or isolated burial?; if in a cemetery, where should the burial be placed? Should it include a mound? If an isolated burial, was a hill, water-side, or road a more appropriate location? This list of choices is an important reminder that burial was probably as much about the living as the dead, and of course the living had the final word. Burials in the early medieval period have been used by scholars for information on such things as religious beliefs, ethnic identity, migration, evidence of communities under duress, political alliances, acculturation, and societal aspirations, and all of these things and others may have played a part. ${ }^{64} \mathrm{At}$ times, each object placed with a burial has been subjected to scrutiny for its possible 'meaning,' and the possibility that an object may have been placed with the dead simply because it was a favoured possession is almost lost in the scholarly desire to ascribe meaning. It is a difficult trap not to fall into, and it is always possible, though not necessarily likely, that the objects in the following discussion, for example the Pórr's hammer pendant found with a burial at Repton, had no extra meaning to the deceased or those burying them than that it was a favoured possession. ${ }^{65}$

A number of inferences may be suggested from the various broad categories of Scandinavan burial outlined above. Firstly, despite the primary written sources, and indeed some more recent works, often lumping all Scandinavian groups together, this is likely to obscure the historical reality of different peoples from different places with different

62 Newman, "The Cumwhitton Viking Cemetery," 21.

${ }^{63}$ J. Graham-Campbell quoted in M. Pitts, "Cumbrian Heritage," British Archaeology 79 (2004), <www.britarch.ac.uk/ba/ba79/feat3.shtml> [23 August 2012].

64 For a review see M. Carver, "Agency, Intellect and the Archaeological Agenda," in M. Carver, S. Semple and A. Sanmark (eds), Signals of Belief in Early England: Anglo-Saxon Paganism Revisited (Oxford: Oxbow Books, 2010), 1-20.

65 The Dórr's hammer pendants will be discussed below. 
cultures. The sheer variety of Scandinavian burial types present in England strongly suggests people migrating from more than one location. Secondly, monumental Scandinavian burials, those which marked the landscape and would have been alien to the contemporary sensibilities of the Anglo-Saxon population, are relatively widespread but few. ${ }^{66}$ This may suggest that the need for such memorials was short-lived, and/or that multiple examples were not considered necessary at the same location. Finally, the churchyard burials suggest conversion to Christianity, or at least acculturation to local Anglo-Saxon burial practices. The remarkable concentration of Scandinavian burial types found in Derbyshire at Heath Wood and Repton provide an ideal opportunity to test some of these inferences.

As mentioned above, the cremation barrow cemetery at Heath Wood is perhaps the clearest indication of a Scandinavian population migrating directly from Scandinavia. Although many of the migrants may be thought to have embarked from Ireland and northern Francia, the absence of cremation barrow cemeteries in those places makes it unlikely that that was where those cremated at Heath Wood were from. ${ }^{67}$ Instead, parallels have been drawn to cremations in Denmark, Sweden, and Norway, and those buried at Heath Wood may have arrived soon enough from Scandinavia to both remember the details of the cremation rites, and to not be overly influenced by other burial customs. ${ }^{68}$ The Heath Wood cemetery is on a small bluff overlooking the River Trent, so the barrow cemetery, and the smoke from those cremations conducted in situ, may have been easily identifiable for those travelling through the region, including by boat. ${ }^{69}$ The decision to locate the cemetery at a visible site

66 Although such burials were part of the pre-Scandinavian Anglo-Saxon landscape and their own presumably remembered past.

67 For the likelihood of Scandinavians embarking for England from Ireland see C. Downham, Viking Kings of Britain and Ireland: The Dynasty of Ívarr to A.D. 1014 (Edinburgh: Dunedin Academic Press, 2007). For Frisia see A. Woolf, From Pictland to Alba 789-1070, The New Edinburgh History of Scotland, vol. 2 (Edinburgh: Edinburgh University Press, 2007), 71-72. Although Woolf suggests that Scandinavians from Frisia settled in Ireland for over a decade before emigrating to England, I consider it more likely that they went directly to England. The evidence for these migrations is outlines in McLeod, The Beginning of Scandinavian Settlement in England, ch. 3.

68 For parallels see Richards, "Excavations at the Viking Barrow Cemetery at Heath Wood," 96.

69 Ibid., 25. However Graham-Campbell, "Pagan Scandinavian Burial,"110, does not believe that the mounds themselves would have been physically imposing. 
could suggest a group who were proudly asserting their cultural origins to their neighbours, both Scandinavian and Anglo-Saxon. The use of cremation, along with animal sacrifice, marks the cemetery as pagan and foreign in ninth-century Anglo-Saxon England.

St Wystan's at Repton is also on the Trent and only four kilometres south-west of Heath Wood, but the Scandinavian burials found there are very different, although both sites were used to bury members of the same army. The mass burial under a mound described above may sound markedly pagan, especially if its completion included pagan rites involving the sacrifice of those buried at the edge of the mound, and this is probably how it appeared to the local Anglo-Saxon population, particularly to any members of the local monastic community witnessing the destruction of their building and the stacking of human bones. But this is not necessarily how the Scandinavians would have considered it. Radio-carbon dating of sixteen bones from the burial returned dates from the seventh through to the late ninth centuries, so although some were likely to belong to members of the great army which created the burial in 873-874, others are clearly much earlier and are likely to derive from the monastic community. ${ }^{70}$ If the disused building was a mortuary chapel as suggested by the excavators then some of the bones may have come from there, but most are likely to derive from the Scandinavian earthwork. ${ }^{71}$ The construction of the defensive ditch through the churchyard disturbed a number of burials and it may have been these remains which were placed into the mass burial. ${ }^{72}$ The moving of disturbed burials would account for both the lack of small bones in the mass burial and their disarticulated state before they were stacked. ${ }^{73}$ The four proposed sacrifice victims also returned radiocarbon dates spanning two centuries, making it possible that the grave also included older burials added to the recently deceased in another ritual burial. ${ }^{74}$ The reburial of disturbed

70 Biddle and Kjølbye-Biddle, "Repton and the 'great heathen army' 873-4," 74, table 4.1.

${ }^{71}$ For the suggestion that the two-celled stone building was a mortuary chapel, see ibid., 67.

${ }^{72}$ For the earthwork and its relationship to the churchyard burials see ibid., 57-60 and fig. 4.8.

${ }^{73}$ J.D. Richards, "Pagans and Christians at a Frontier: Viking Burial in the Danelaw," in M.O.H. Carver (ed.), The Cross Goes North: Processes of Conversion in Northern Europe, AD 300-1300 (York: York Medieval Press, 2003), 383-395, at 389-390.

${ }^{74}$ Hall, Exploring the World of the Vikings, 85. These radiocarbon results are not presented in the original article (Biddle and Kjølbye-Biddle, "Repton and the 'great heathen 
remains, although not done in a particularly Christian manner, does show a certain amount of respect and consideration for the dead. ${ }^{75}$ It obviously would have been much less time consuming to leave the disturbed remains where they were. Indeed, in the assembling of bones in a chamber the Scandinavians may have been influenced by Anglo-Saxon burial practices at St Wystan's. It has been noted that the recesses in the crypt which were used for important human remains are not large enough to hold a body, being only 152.4 centimetres wide and 91.4 centimetres deep. Consequently, it is thought that the recesses held not bodies but bones in caskets, which had been buried and then dug up after the flesh had decayed. ${ }^{76}$ These collections of bones in recesses against the crypt's walls, which were also likely to be missing many of the smaller bones, are reminiscent of what the Scandinavians did with the bones in the mound burial, and considering that the Scandinavians were in occupation of the church they had no doubt investigated the crypt.

army' 873-4," appendix A, 87-92), so Hall must be referring to further unpublished results.

75 Richard, "Pagans and Christians at a Frontier," 390.

${ }^{76}$ For the dimensions of the recesses see H.M. Taylor, St Wystan's Church Repton: A Guide and History (Derby: J.M. Tatler and Sons, 2002 [rev. edn]), 18. For the suggesting regarding the recesses see the "Repton crypt" entry on the website of St Wystan's church <www.reptonchurch.org.uk> [22 September 2012]. For a photograph of the crypt, see Figure 2. 


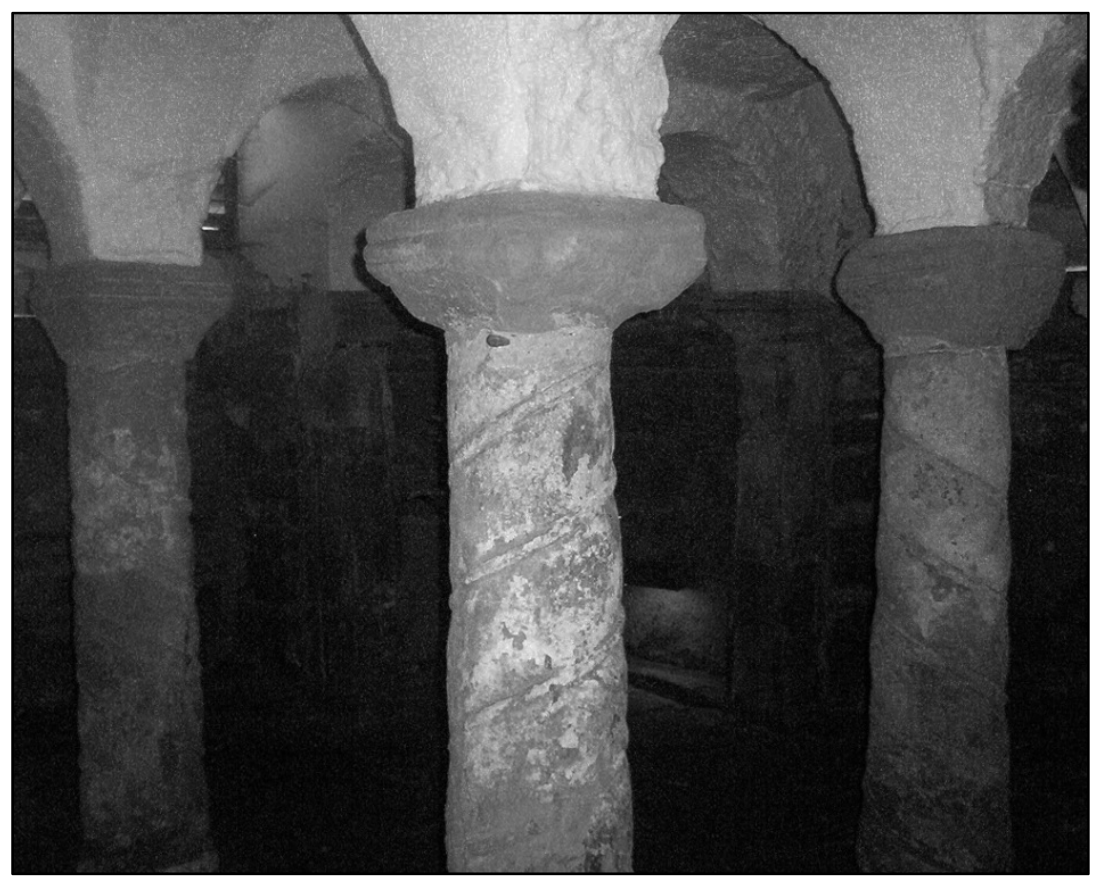

Figure 2: Anglo-Saxon crypt of St Wystan's Repton.

Source: Photography by Shane McLeod with the kind permission of St Wystan's, Repton.

The respect shown in reburying the disturbed remains of the ancestors of the recently conquered kingdom also hints at appropriation. The burials under the mound included the remains of those who had been associated with the surrounding land in the past, perhaps including members of the Mercian royal family, and probably recent remains of some Scandinavians, the new rulers of the land. ${ }^{77}$ Consequently, the burial effectively combined the remains of the new and earlier rulers, as did the re-use of barrows at Aspatria and Claughton Hall. All of these burials may

77 St Wystan's was the burial place of a number of Mercian kings and claimants to the throne, Biddle and Kjølbye-Biddle, "Repton and the 'great heathen army' 873-4," 50. Of the four individuals from the mass burial selected for stable isotope analysis one, a female, is likely to have grown up in mid-Continental or Baltic Europe, and her results are similar to a Scandinavian male buried in the churchyard. For the results see Budd et al., "Investigating Population Movement," 137-138. For a discussion of the presence of women with a Scandinavian army see S.H. McLeod, "Warriors and Women: The Sex Ratio of Norse Migrants to Eastern England up to 900 AD," Early Medieval Europe 19 (2011), 332-353. 
journal of the auscralian early medieval associacion

be seen as an attempt to create a sense of continuity and legitimacy, inserting the Scandinavian dead into monuments that marked the landscape. However the construction of new mounds, such as those at Hesket-in-the-Forest, Repton, and possibly Hook Norton, involved considerable time and effort, suggesting that they were important to those who constructed them. The Repton burial in particular involved the labour-intensive task of demolishing a building to ground level, laying down a layer of clean red marl on the surface, sorting and stacking the bones of 264 people, and then building a mound and stone kerb, and killing and burying the proposed sacrificial victims. ${ }^{78}$ Repton, which was a new mound incorporating older remains, may thus be seen as a special burial, perhaps a visible political statement by the new rulers of Mercia at a site associated with the kingdom's previous rulers. ${ }^{79}$ In creating the mound burial the Scandinavians were appropriating both the site and the remains of some of its former inhabitants.

The mounds at Repton and Heath Wood were geographically close but quite different. The Heath Wood cemetery had multiple small barrows, Repton one large one. Although both examples were constructed by members of the same army, the different burial rites suggest that they were serving different groups within the army, which may in part explain the closeness of the burial sites. It is a very different situation in the north-west. The most northerly Scandinavian barrow was the one at Aspatria, which is approximately 22 kilometres from the barrow at Hesket-in-the-Forest. Although close by modern standards, this still represents a not-inconsiderable distance by horse or foot. However the use of inhumation at Aspatria and cremation at Hesket may suggest that these burials served different Scandinavian communities. Claughton Hall is a further 96 kilometres, or two days by horse, south from Hesketin-the-Forest. ${ }^{80}$ If the two Scandinavian burials added to earlier man-made features that were not mounds are included in this discussion, Ormside is 48 kilometres from Hesket-in-the-Forest, and Rampside is approximately 70 kilometres from Claughton Hall, or closer if a boat is taken across Morecambe Bay. When these burials in landscape features in north-west England are considered there does appear, with the exception of Aspatria and Hesket-in-the-Forest, to have been one Scandinavian burial in a

78 Biddle and Kjølbye-Biddle, "Repton and the 'great heathen army' 873-4," 72-74.

79 Richards, "Pagans and Christians at a Frontier," 390-391.

80 It has been estimated that on a multi-day journey a horse could carry a rider 50 kilometres per day: C. Gillmor, "War on the Rivers: Viking Numbers and Mobility on the Seine and Loire, 841-886," Viator 19 (1988), 79-109 at 105. 
visible landscape feature every day or so for someone riding through the Scandinavian settlement areas in the north-west. Or to consider the evidence from another perspective, there was perhaps one visible burial per local Scandinavian community. Of course there may have been other barrows that were destroyed before being recorded, such as the burial at Eaglesfield, Cumbria, ${ }^{81}$ but the impression of burials in landscape features not being close together, certainly not within view of each other, prevails. There must have been many more Scandinavian burials in the north-west than there are barrows, so it was presumably decided that one prominent burial in each locality would suffice.

To return to Repton, some Scandinavian burials at the site display a degree of acculturation. The three certain Scandinavian burials in the churchyard are dated to 873-874, that is, before the first recorded Scandinavian settlement and whilst the great army was still actively campaigning. Despite this, there are indications that these burials are Christian, or at least that local burial customs had been adopted to some degree. This implies that Scandinavian acculturation to Anglo-Saxon culture was occurring before settlement, and certainly before Guthrum and some of his leading followers accepted baptism as part of the agreement reached with Alfred of Wessex in $878 .{ }^{82}$ Although the burial with multiple grave-goods may seem to be pagan, indeed it included a Pórr's hammer pendant, it and the two others with minimal grave-goods were aligned in the standard Christian way and were buried close to the church, with one of the graves actually touching a church wall. ${ }^{83}$ There are few holier places to be buried in a churchyard. Furthermore, the grave which included the Pórr's hammer is thought to have been the first burial in that part of the churchyard. ${ }^{84}$ That it and the two subsequent Scandinavian burials were aligned in the Christian manner is therefore significant as they were not simply following the alignment of the existing graves, but those burying them actively chose the alignment. Considering the amount of damage that the church building suffered during the stay of the great army it would appear unlikely that members of the monastic

81 The Eaglesfield burial is described as a mound burial in Hadley, The Vikings in England, 241, a possible mound burial in Richards, Viking Age England, 193, but Redmond, Viking Burial in the North of England, 106, does not mention a mound and suggests that the inhumation was in a Christian cemetery.

82 ASC 878 (Swanton, The AngloSaxon Chronicles, 76).

83 Biddle and Kjølbye-Biddle, "Repton and the 'great heathen army' 873-4," 61 and 66, fig. 4.11.

84 Ibid., 66. 
community would have remained and helped bury the Scandinavian dead, so instead it may be thought that the alignment was chosen by Scandinavians. With this in mind, the Christian alignment of the graves in the cemetery at Cumwhitton discussed above might not be mere chance. It may also be significant that the crypt which housed the shrine of St Wystan at Repton appears to have remained intact during the Scandinavian occupation. ${ }^{85}$ Indeed, the new Scandinavian burials and the small stone mound over the most elaborate burial would have been visible from the north-facing window in the crypt, thereby creating a possible association between the Scandinavian burials and the saint. ${ }^{86}$ The other early Scandinavian churchyard burial, at St Mary's, Reading, also displays significant evidence of acculturation. As mentioned above it is thought that the coffin burial with minimal grave goods is related to the great army winter camp at Reading in 870-871, the same as the dating given for the isolated weapon burials at Reading and Sonning on opposite banks of the River Thames. If this dating is correct, then it is surely significant that a decision was made by the living to place the burial in a churchyard rather than on the banks of the Thames. Although it is possible that the alignment of the Repton burials was dictated by the church building rather than religious considerations, and that churchyards were simply a convenient place to bury the dead (especially at Repton where part of the churchyard was inside the winter camp enclosure), I consider the St Mary's, Reading, and St Wystan's, Repton burials to be early examples of transitional burials. If this is correct, then the quick acculturation to Anglo-Saxon/Christian burial forms raises the possibility that some Scandinavians had arrived in England with an understanding of Christian burial customs, and perhaps Christianity itself.

The quick adoption of Christian burial customs by some of the Scandinavians begs the question "where had the practice been learnt?" It is possible that it had occurred in England, although the very early Christian-style burials at Reading and Repton less than a decade after the great army arrived perhaps make this unlikely. ${ }^{87}$ Some Scandinavians living in Scandinavia had become familiar with Christianity: by the midninth century a number of Scandinavians, probably merchants, residing at

\footnotetext{
85 Richards, "Pagans and Christians at a Frontier," 388.

${ }^{86}$ For the windows in the crypt see Taylor, St Wystan's Church, 18.

${ }^{87}$ For the arrival of the great army see ASC 866 (Swanton, The Anglo-Saxon Chronicles, 68).
} 
Birka and Hedeby had been baptised at Dorestad and Hamburg. ${ }^{88}$ Archbishop Ebo of Reims preached in Denmark in 823 and in 826 the king of Denmark, Harald Klak, was baptized in Mainz before returning home accompanied by the missionary Anskar, who intended to continue the work of Ebo. ${ }^{89}$ This mission ended abruptly when Harald was exiled in 827 , but following a mission to Birka in Sweden which resulted in a church being built, Anskar was able to return to Denmark in the middle of the century when he was successful in establishing churches in the trading centres of Hedeby and Ribe. ${ }^{90} \mathrm{He}$ is also reported to have earlier established a school to educate some Danish boys in a Christian manner. ${ }^{91}$ Furthermore, international trading centres are likely to have included foreign Christian merchants, with Hedeby thought to have had resident populations of Frisians, Saxons, and Franks, and there is evidence for Franks / Frisians, including women, living at Kaupang, Norway, during the ninth century. ${ }^{22}$ Despite these possibilities, the Scandinavians in England were more likely to have become acquainted with Christianity in Ireland or Frisia. Scandinavian settlements had been established in Frisia intermittently from 826 and Dublin from 841, considerably earlier than the Scandinavian settlements in England from 876. ${ }^{93}$ As both Francia and Ireland were Christian kingdoms, Scandinavians living there are likely to

88 Rimbert, Vita Anskarii, 24 and 27 (C.H. Robinson [trans.], Anskar the Apostle of the North 801-865 (Croydon: The Society for the Propagation of the Gospel in Foreign Parts, 1921), 84 and 93.

${ }^{99}$ Ibid., 7 (Robinson, Anskar, 38-40).

90 Ibid., 11 (Robinson, Anskar, 48); 24 (Robinson, Anskar, 82-83); 26 (Robinson, Anskar, 89); 28 (Robinson, Anskar, 95); and 32 (Robinson, Anskar, 102-103).

${ }^{91}$ Ibid., 8 (Robinson, Anskar, 44).

92 The inference on resident populations is based on excavations of the Hedeby cemeteries, M. Müller-Wille, "Hedeby," in P. Pulsiano (ed.), Medieval Scandinavia: An Encyclopedia, Encyclopedias of the Middle Ages (New York: Routledge, 1993), 273275, at 275. Frankish/Frisian residents at Kaupang is suggested by cooking traditions and finds of metalwork and pottery, much of which was associated with a single building, D. Skre, "From Dorestad to Kaupang," in A. Willemsen and H. Kik (eds), Dorestad in an International Framework: New Research on Centres of Trade and Coinage in Carolingian Times (Turnhout: Brepols, 2010), 137-141, at 139.

${ }^{93}$ For England see ASC 876 (Swanton, The Anglo-Saxon Chronicles, 74). For Dublin see S. Mac Airt and G. Mac Niocaill (eds and trans.), The Annals Of Ulster (to A.D. 1131), part 1: Text and Translation 841 (Dublin: Dublin Institute for Advanced Studies, 1983), 299. For Scandinavian groups granted Frisia see J.L. Nelson (trans.), Ninth-Century Histories, vol. 1: The Annals of St Bertin, Manchester Medieval Sources Series (Manchester: Manchester University Press, 1991); and T. Reuter (trans.), Ninth-Century Histories, vol. 2: The Annals of Fulda, Manchester Medieval Sources series (Manchester: Manchester University Press, 1992). 
journal of the auscralian early medieval associacion

have been regularly exposed to the Christianity of the local population. There is historical, archaeological, and place-name evidence for Scandinavians from Ireland invading and settling in England from 865, ${ }^{94}$ and place-name and later textual evidence for settlers from Frisia. ${ }^{95}$ Considering Ireland and Frisia as part of the cultural background of the Scandinavians in England helps us to understand the evidence for early acculturation.

As the evidence demonstrates that some of the Christian or transitional Scandinavian burials occurred earlier than some of the pagan burials, for example the $c .871$ burial in St Mary's churchyard, Reading, is likely to be earlier than the $c .873-878$ cremations at Heath Wood and much earlier than the cremation at Hesket-in-the-Forest dated to the early tenth century, it is not surprising that pagan burials do not appear to have continued for long. It is likely that only the first generation of immigrants, and not even all of them, were buried in non-Christian style as their children probably adapted to the Christian society in which they grew up. ${ }^{96}$ Consequently, pagan burials in eastern England, which was settled from 876, and in the north-west, settled from c. 900 or earlier, dated after 900 and 925 respectively, are most likely to represent the burials of new Scandinavian immigrants. By 950 non-Christian burial in England appears to have ceased.

The acculturation process is also evident in finds of ornamental metalwork, including possible evidence of Anglo-Saxons adopting aspects of Scandinavian culture. There has been a significant increase in the number of finds of Scandinavian-style jewellery in the last two decades due to the use of metal-detectors, and reporting to the Portable Antiquities Scheme. Perhaps surprisingly, considering traditional views of Scandinavian settlement in England, it has been noted that there are more

94 See in general Downham, Viking Kings of Britain and Ireland. 'Ireby/Irby' names combine the Old Norse -by, settlement, with 'Irish': however it is thought that they are more likely to represent the settlement of Scandinavians who had come from Ireland than actual Irish settlers, R.H. Bremmer Jr, "Frisians in Anglo-Saxon England: A Historical and Toponymical Investigation," Fryske nammen 3 (1981), 45-94, at 78.

95 For Scandinavians from Frisia attacking York in 866 see Woolf, From Pictland to Alba 789-1070, 71-72. The place-names Frisby, Firsby and Friesthorpe also suggest Scandinavian settlers from Frisia, Bremmer Jr, "Frisians in Anglo-Saxon England," 62-63.

96 Most famously Oda, archbishop of Canterbury, was the son of a member of the great army. For the likely acculturation of the children on Scandinavian migrants, including Oda, see D.M. Hadley and K.A. Hemer, "Microcosms of Migration: Children and Early Medieval Population Movement," Childhood in the Past 4 (2011), 63-78, at 72-75. 
Scandinavian female dress items than those worn by men. ${ }^{97}$ Kershaw considers that the Scandinavian-style jewellery had probably "been introduced to England on the clothing of female settlers from Scandinavia, rather than items having arrived as trade goods for the mass market."98 Yet significantly, the use of Anglo-Saxon rather than Scandinavian-style pin fittings on a significant number of the Scandinavian-style (rather than Anglo-Scandinavian) brooches demonstrates that many were made locally, ${ }^{99}$ and could suggest that they were adapted to also be worn by the Anglo-Saxon population. ${ }^{100}$ The process of acculturation continued with the manufacture of AngloScandinavian brooches, wherein the two brooch forms merged, often with an Anglo-Saxon shaped (disc) brooch bearing Scandinavian art motifs. ${ }^{101}$

However, this high level of acculturation is not seen in another form of jewellery, that of Pórr's hammer pendants. Along with cremation and the possibility of human sacrifice at Repton, Pórr's hammer pendants are the clearest indication of Scandinavian pagan religious affiliation due to their association with the Scandinavian god. ${ }^{102}$ The Dórr's hammer pendants found in England, of which there are at least eighteen known in 2013, suggests that they were worn as pagan, and Scandinavian, amulets marking their wearers as different from the Anglo-Saxon population. ${ }^{103}$

${ }^{97}$ K. Leahy and C. Paterson, "New Light on the Viking presence in Lincolnshire: The Artefactual Evidence," in J. Graham-Campbell, R. Hall, J. Jesch, and D.N. Parsons (eds) Vikings and the Danelaw: Select Papers from the Proceedings of the Thirteenth Viking Congress (Oxford: Oxbow Books, 2001), 181-202, at 197; and J.F. Kershaw, "Culture and Gender in the Danelaw: Scandinavian and Anglo-Scandinavian brooches," Viking and Medieval Scandinavia 5 (2009), 295-325, at 306.

98 Kershaw, "Culture and Gender in the Danelaw," 299.

99 Ibid., 299-300, and 310 for a specific example.

100 Cf. Leahy and Paterson, "New Light on the Viking Presence in Lincolnshire," 193, who acknowledge "the possibility that local women adapted their dress to suit Scandinavian fashions."

101 Ibid., 196-197. Kershaw, "Culture and Gender in the Danelaw," 318-319.

102 Other possible indications are figurative mounts or appliqués and oval brooches. For the former see T. Pestell,"'Imports or Immigrants? Reassessing Scandinavian Metalwork in Late Anglo-Saxon East Anglia," in D. Bates and R. Liddiard (eds) East Anglia in its North Sea World (Woodbridge: Boydell Press, 2013), 230-255, at 243. I would like to thank the author for sending me a copy of this article prior to publication. For oval brooches see McLeod, The Beginning of Scandinavian Settlement in England, ch. 6.

103 See Pestell, "Imports or Immigrants?" 242. In museum collections I am aware of single Thor's hammers at Derby Museum and Art Gallery, Saffron Walden Museum, 
journal of the auscralian early medieval associacion

Furthermore, the discovery of three or four hammer pendants at the Torksey productive site, dated to the great army winter camp of 872-873 and where possible evidence of the minting of coin forgeries has been recovered, could indicate that the pendants were being made by Scandinavians in England before they began to settle. ${ }^{104}$ Even if Dórr's hammer pendants were not being manufactured in England as early as the campaigns of the great army, there is the possibility that expensive silver versions with gold filigree were being produced at a workshop in Norfolk, suggesting that there "was a large enough pagan clientele to commission them." 105 If the hammers were a pagan reaction to Christianity as Staeker suggests, it suggests that most of the Dórr's hammers would have belonged to first generation immigrants, including members of the great army. ${ }^{106}$ The discovery of Dórr's hammer on a necklace of the man buried at Repton, a probable member of the great army, supports this position. ${ }^{107}$ So too does the fact that the majority of the hammer pendants thus far have been found in East Anglia, which submitted to Wessex in 917: it is likely that Christianity was an important aspect of integration with Wessex and therefore pagan amulets may not have been tolerated.

Despite the possibility of a number of Scandinavian immigrants using Pórr's hammer pendants to signify their ethnicity and non-Christian status (but only if the pendants were worn conspicuously on top of rather than under their clothing), the number of hammer pendants recovered is minor compared to other forms of jewelry that do suggest that

and Jewry Wall Museum, Leicester, six in Castle Museum, Norwich, and two in the British Museum found at Leconfield, East Yorkshire, and near Carlisle, Cumbria. To these can be added the three or four found at Torksey, and another was found in the Cuerdale hoard, Lancashire. Other single examples were found at Wetwang, East Yorkshire, and Sibton, Suffolk. There is also one from Norwich known from an auction catalogue. See "Treasure record 2002 T168," Portable Antiquities Scheme, <www.finds.org.uk> [10 March 2012]; Pestell, "Imports or Immigrants?” 242.

104 M. Blackburn "The Viking Winter Camp at Torksey, 872-3," in M. Blackburn, Viking Coinage and Currency in the British Isles, British Numismatic Society Special Publication, vol. 7 (London: Spink Books, 2011), 221-264, at 233, for the hammer pendants and 225 and 228 for the possibility of coin production.

105 Pestell, "Imports or Immigrants?" 242. Based on the similarity of two East Anglian hammer pendants, from Norfolk and Great Witchingham.

106 J. Staecker, "Thor's Hammer - Symbol of Christianization and Political Delusion," Lund Archaeological Review 5 (1999), 89-104, at 89-99.

107 Biddle and Kjølbye-Biddle, "Repton and the 'Great Heathen Army,' 873-4,” 61. 
acculturation was underway. ${ }^{108}$ Furthermore, as argued above, there are possible signs of acculturation with the Repton burial, even if it was due to those burying the warrior rather than the wishes of the man himself. Instead, the evidence from the growing corpus of ornamental metalwork is similar to that of the burial record. There is evidence of traditional (pagan) Scandinavian practices and religious beliefs being introduced to England by the immigrants, but the majority of the evidence suggests that those continuing to publicly display such beliefs were soon in the minority. Instead, most of the Scandinavian immigrants soon entered into a process of acculturation with the Anglo-Saxon population, resulting in transitional burials in churchyards and jewellery which included aspects of Anglo-Saxon design. Indeed, this process may be evident as early as the c. 871 burial in St Mary's churchyard at Reading, and to have commenced in the Scandinavian settlements in Ireland and Frisia.

To return to the notion of the Scandinavians in England in the midninth to mid-tenth centuries appearing to the Anglo-Saxons as barbarians, there is little in the contemporary historical record to support the notion, other than in Asser who highlights the non-Christian status of the Scandinavians. The clearest difference between the two groups can be seen in the burial record, on which the historical sources, even the later ones which are often the most biased against the Scandinavians, are largely silent. Indeed, this silence in the sources about burials which were clearly visible in the medieval landscape raise interesting questions about the written sources that is worthy of further consideration. Although there was the occasional use of cremation and barrows by the Scandinavian immigrants, there are indications of their early adoption of Christian/Anglo-Saxon burial practices, even if grave-goods were included. Despite the enduring perception of 'Vikings' in popular portrayals as one of the most obvious and easily identifiable barbarian groups, this does not appear to have been the opinion of the contemporaries in England who produced the primary written sources.

108 For example the eighteen or nineteen Pórr's hammers noted above for all of England is still less than the twenty-five found at the single site of Storagard, Tissø, Denmark. For the latter see Hall, Exploring the World of the Vikings, 171. 